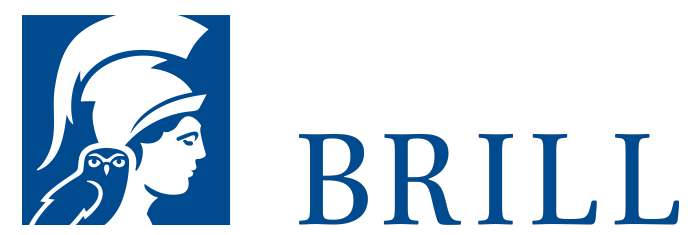

\title{
A Short History of Cardiology
}

\section{Author: Peter Fleming}

The story told in this book begins in about 1700, when the first attempts were made to study the diseased heart in life (the subject matter of cardiology), as distinct from its appearance after death; it ends, rather arbitrarily, in 1970.

The account of the development of knowledge of heart disease is mainly chronological with emphasis on the fruitful consequences of the cross-fertilization of clinical practice with pathological anatomy at the beginning of the nineteenth century and with physiology at the end.

In addition, shorter chapters deals with such topics as specific disease entities, methods of investigation, cardiac surgery and the work of two individuals - Peter Latham, an example of a physician practising with today's clinical skills but a very imperfect knowledge of the pathogenesis of heart disease and Etienne Marey, an early exponent of the clinical physiology which would, in time, throw light on that pathogenesis.

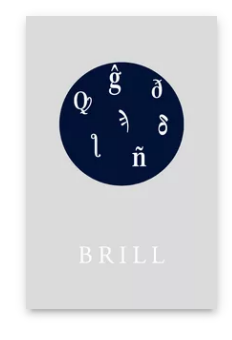

Pages: xviii, 241 pp.

Language:

English

Subjects:

History of

Medicine,

History, Modern

History, History,

Contemporary

History, History

Publisher: Brill

Series:

Clio Medica

Online, Volume:

40

Clio Medica,

Volume: 40

E-Book (PDF)

Released online:

29 Jan 2020

ISBN: 978-90-

04-41850-9

List price

USD $\$ 139.00$

Hardback

Publication date:

O1 Jan 1997

ISBN: 978-90-

420-0048-3

List price

USD $\$ 131.00$ 
Publication date:

O1 Jan 1997

Dr Peter Fleming was a consultant cardiologist for many years, ISBN: $978-90-$ and in addition, had an interest in methods of assessment in medical education. He was among the first to obtain the Diploma in the History of Medicine of the Society of Apothecaries and has lectured on the history of cardiology on many occasions.

For more information see brill.com

Order information: Order online at brill.com +44330 333 0049 | customerservices@brill.com Submission information: brill.com/authors

Titles published by Brill | Fink, Brill | mentis or Brill | Schöningh: +49(o)71 5413279216 | brill@brocom.de 